\title{
Correction to: Testosterone induces renal tubular epithelial cell death through the HIF-1a/ BNIP3 pathway
}

\author{
Yonghan Peng ${ }^{1 \dagger}$, Ziyu Fang ${ }^{1 \dagger}$, Min Liu ${ }^{1 \dagger}$, Zeyu Wang ${ }^{1}$, Ling Li ${ }^{1}$, Shaoxiong Ming ${ }^{1}$, Chaoyue Lu ${ }^{1}$, Hao Dong ${ }^{1}$, \\ Wenhui Zhang ${ }^{1}$, Qi Wang ${ }^{1}$, Rong Shen ${ }^{1}$, Fei Xie ${ }^{1}$, Weitao Zhang ${ }^{2}$, Cheng Yang ${ }^{2,3^{*}} \mathbb{C}$, Xiaofeng Gao ${ }^{1 *}$ and \\ Yinghao Sun ${ }^{1 *}$
}

\section{Correction to: J Transl Med (2019) 17:62} https://doi.org/10.1186/s12967-019-1821-7 Following publication of the original article [1], the authors reported errors in Fig. 2, Fig. 4, Fig. 5 and Fig. 6:

1. The raw data of flow cytometry (Fig. 2, Fig. 4a and Fig. 6b) were disordered.

2. In Fig. $4 \mathrm{~b}$, a wrong image of TUNEL staining of HK-2 cells in the normal group was chosen.
3. In Fig. 5a, the blots of BCL-2 in TCMK-1 and HK-2 were duplicated by unintentional error. In addition, the authors mistakenly chose the same images in cleaved caspase- 9 and cleaved caspase- 3 blots in the TCMK-1 group.

The incorrect and correct figure are included in this Correction article. The original article has been updated.

*Correspondence: esuperyc@163.com; yang.cheng1@zs-hospital.sh.cn; gxfdoc@sina.com; sunyhsmmu@126.com

†Yonghan Peng, Ziyu Fang and Min Liu contributed equally to this article

1 Department of Urology, Shanghai Changhai Hospital, Shanghai 200433,

China

${ }^{2}$ Department of Urology, Zhongshan Hospital, Shanghai Key Laboratory

of Organ Transplantation, Fudan University, 180 Fenglin Road,

Shanghai 200032, China

Full list of author information is available at the end of the article

(c) The Author(s) 2021. This article is licensed under a Creative Commons Attribution 4.0 International License, which permits use, sharing, adaptation, distribution and reproduction in any medium or format, as long as you give appropriate credit to the original author(s) and the source, provide a link to the Creative Commons licence, and indicate if changes were made. The images or other third party material in this article are included in the article's Creative Commons licence, unless indicated otherwise in a credit line to the material. If material is not included in the article's Creative Commons licence and your intended use is not permitted by statutory regulation or exceeds the permitted use, you will need to obtain permission directly from the copyright holder. To view a copy of this licence, visit http://creativeco mmons.org/licenses/by/4.0/. The Creative Commons Public Domain Dedication waiver (http://creativecommons.org/publicdomain/ zero/1.0/) applies to the data made available in this article, unless otherwise stated in a credit line to the data. 


\section{Correct Figure 2:}

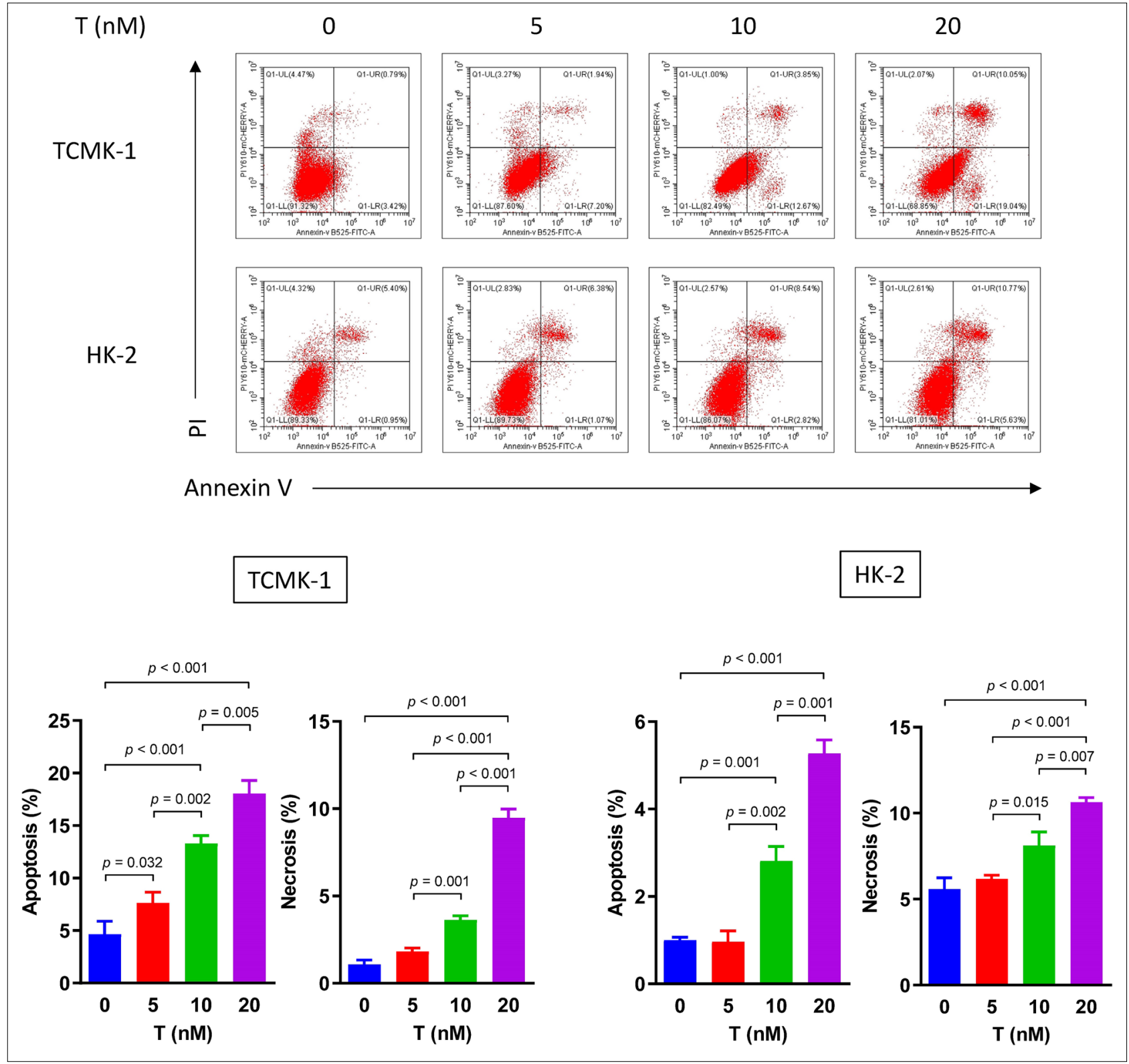




\section{Incorrect Figure 2:}

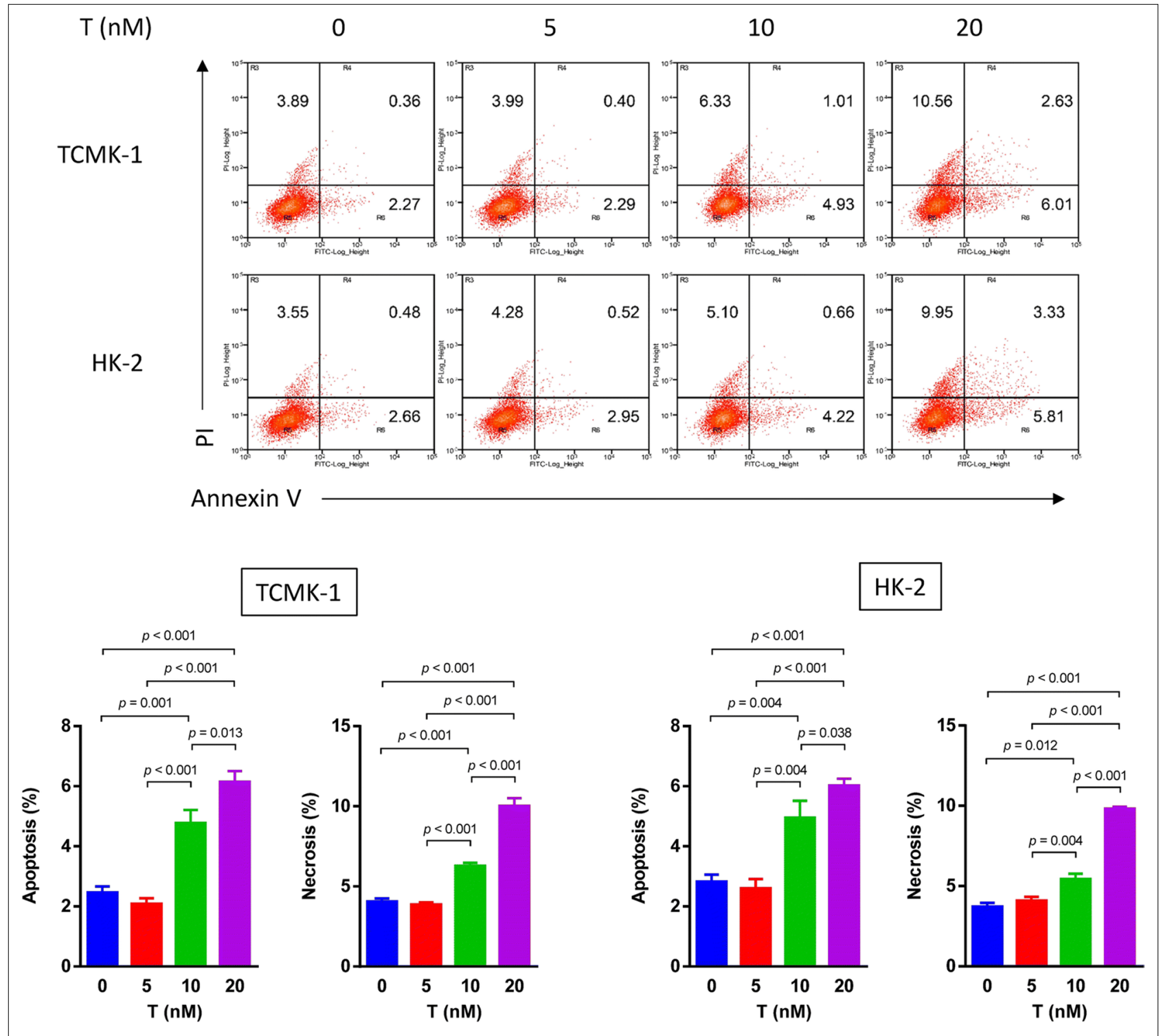




\section{Correct Figure 4:}

a

TCMK-1

HK-2

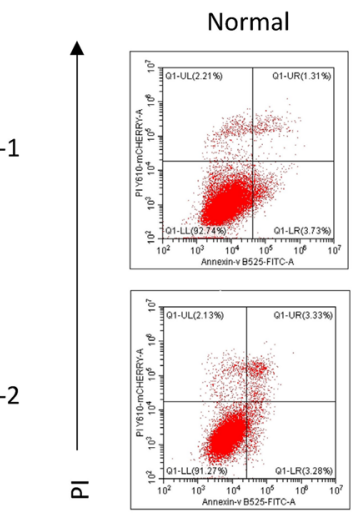

Annexin V
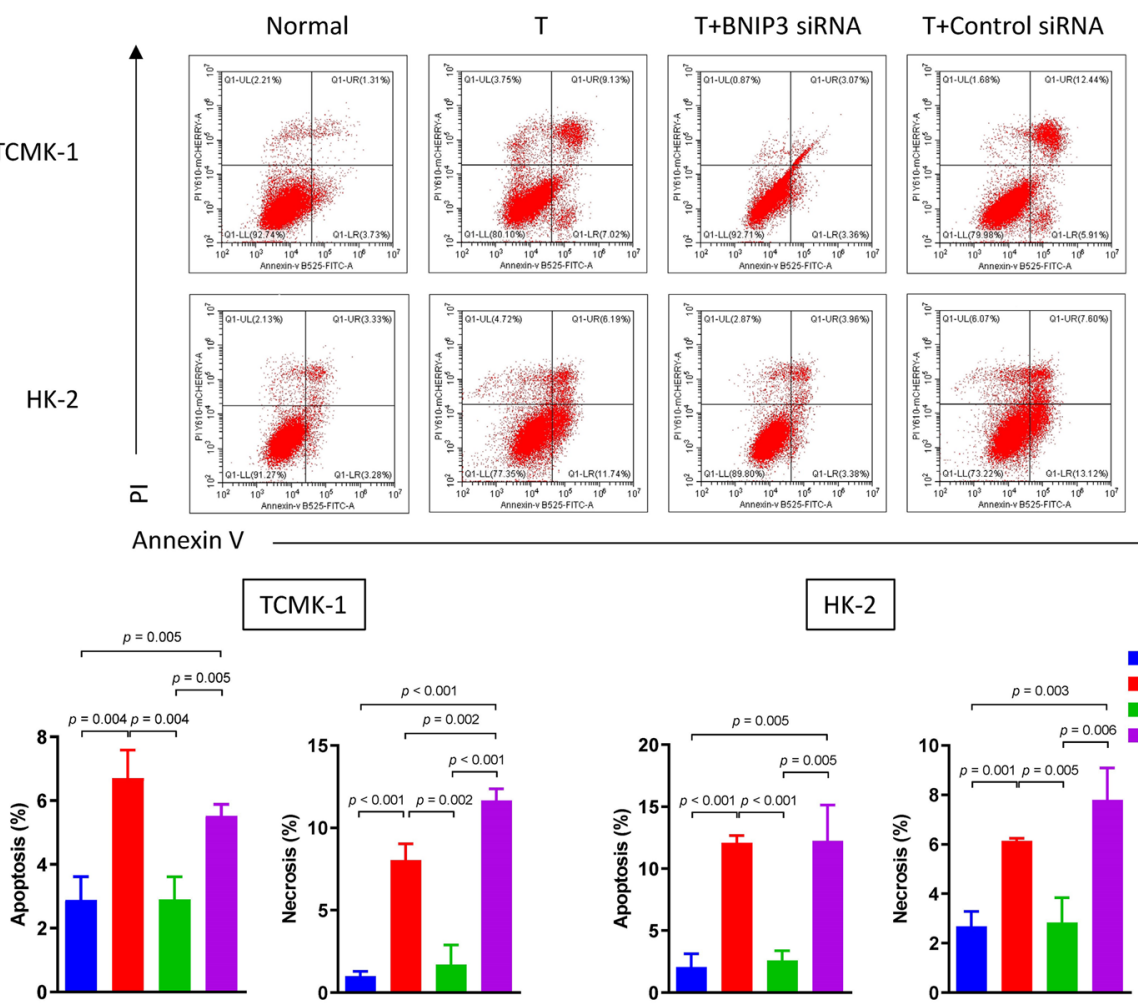

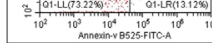

K-2
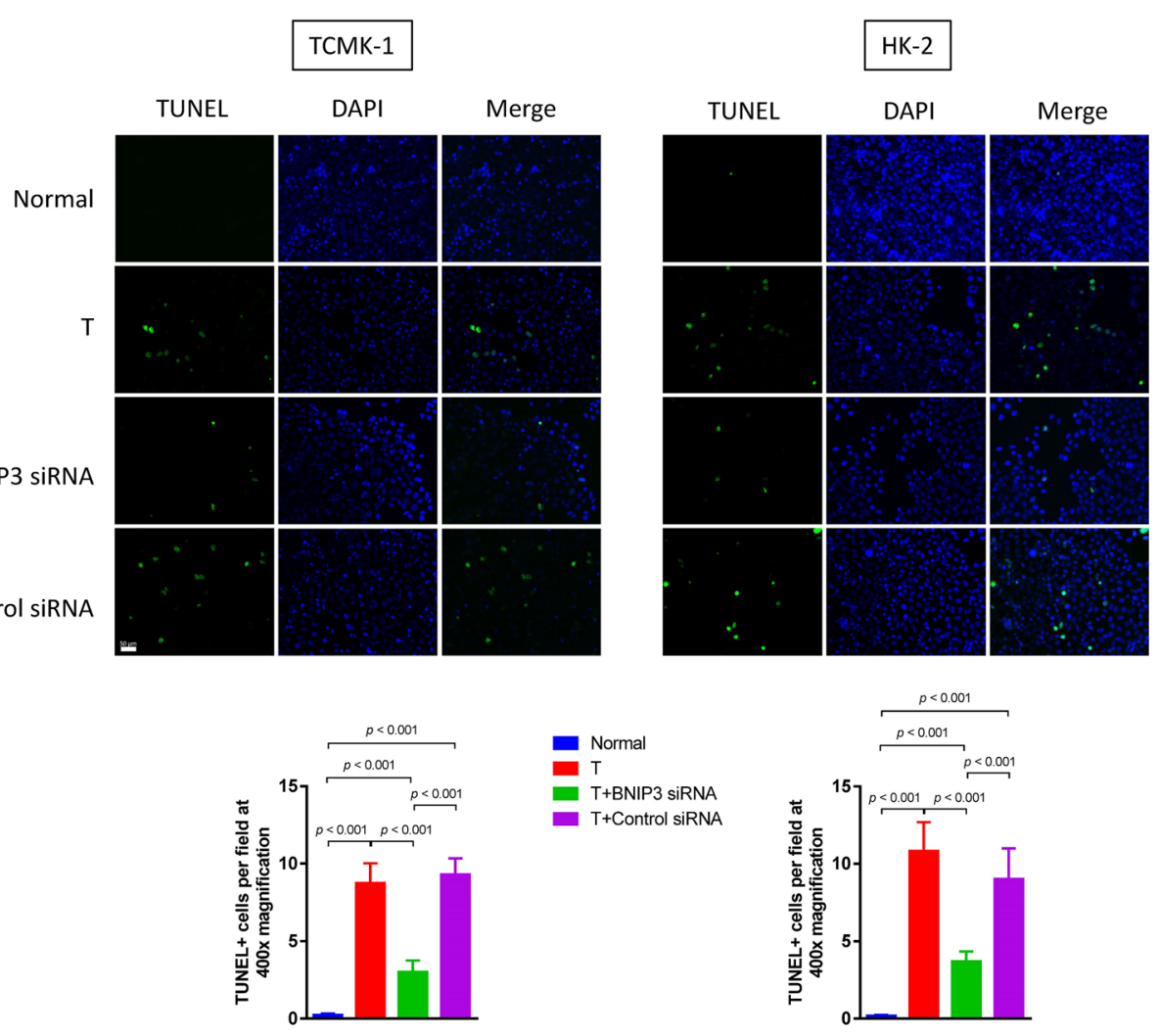


\section{Incorrect Figure 4:}

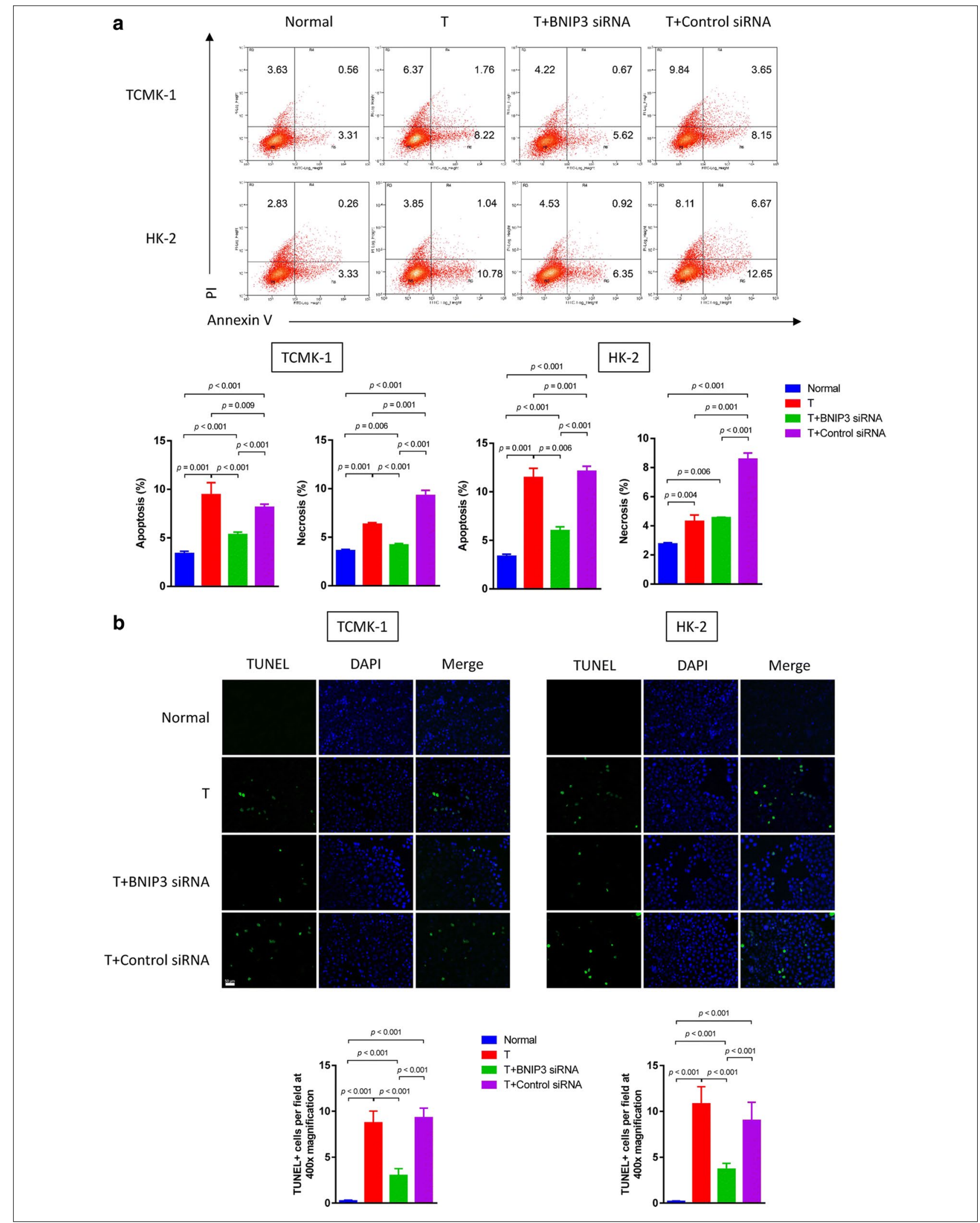




\section{Correct Figure 5:}

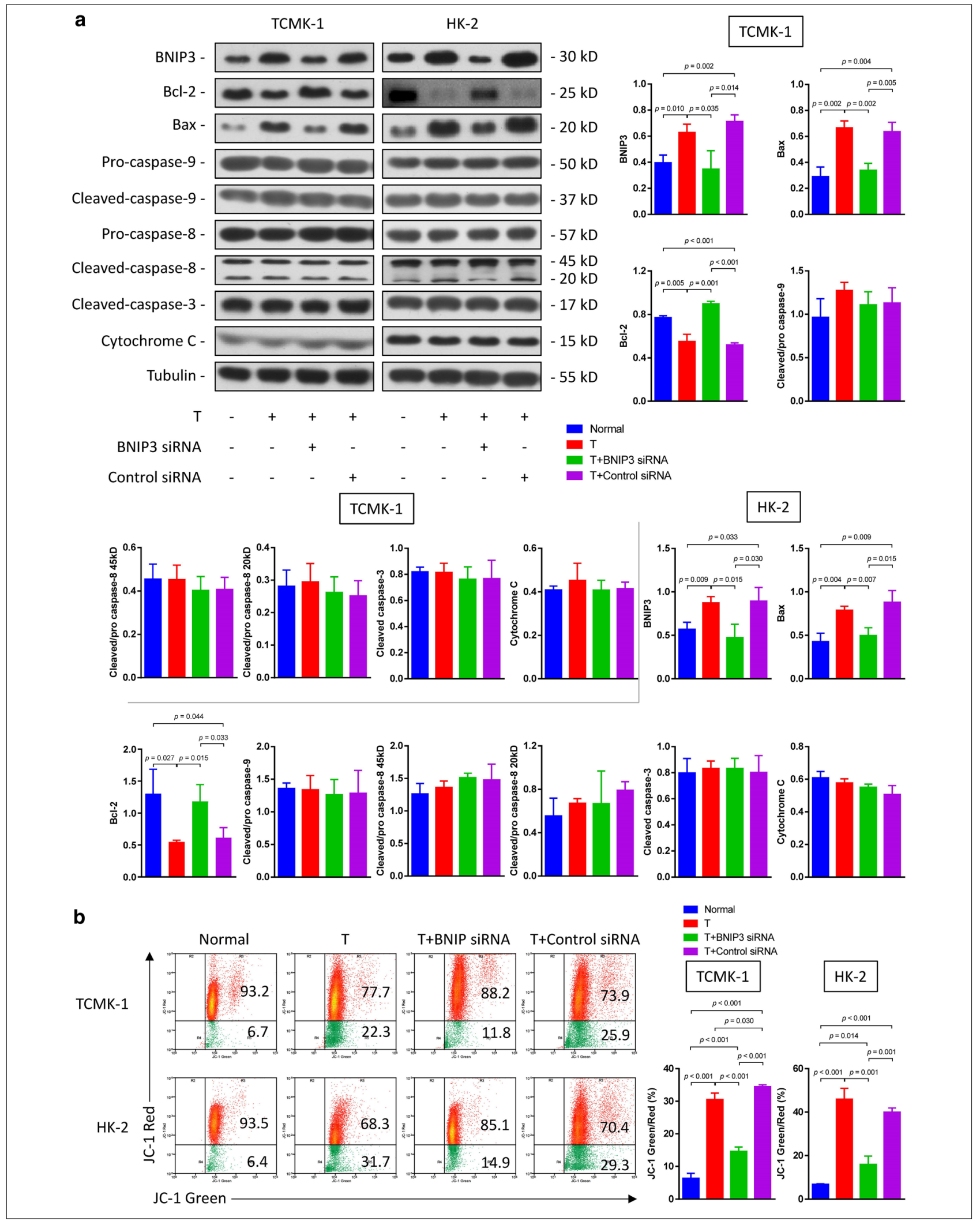


Incorrect Figure 5:

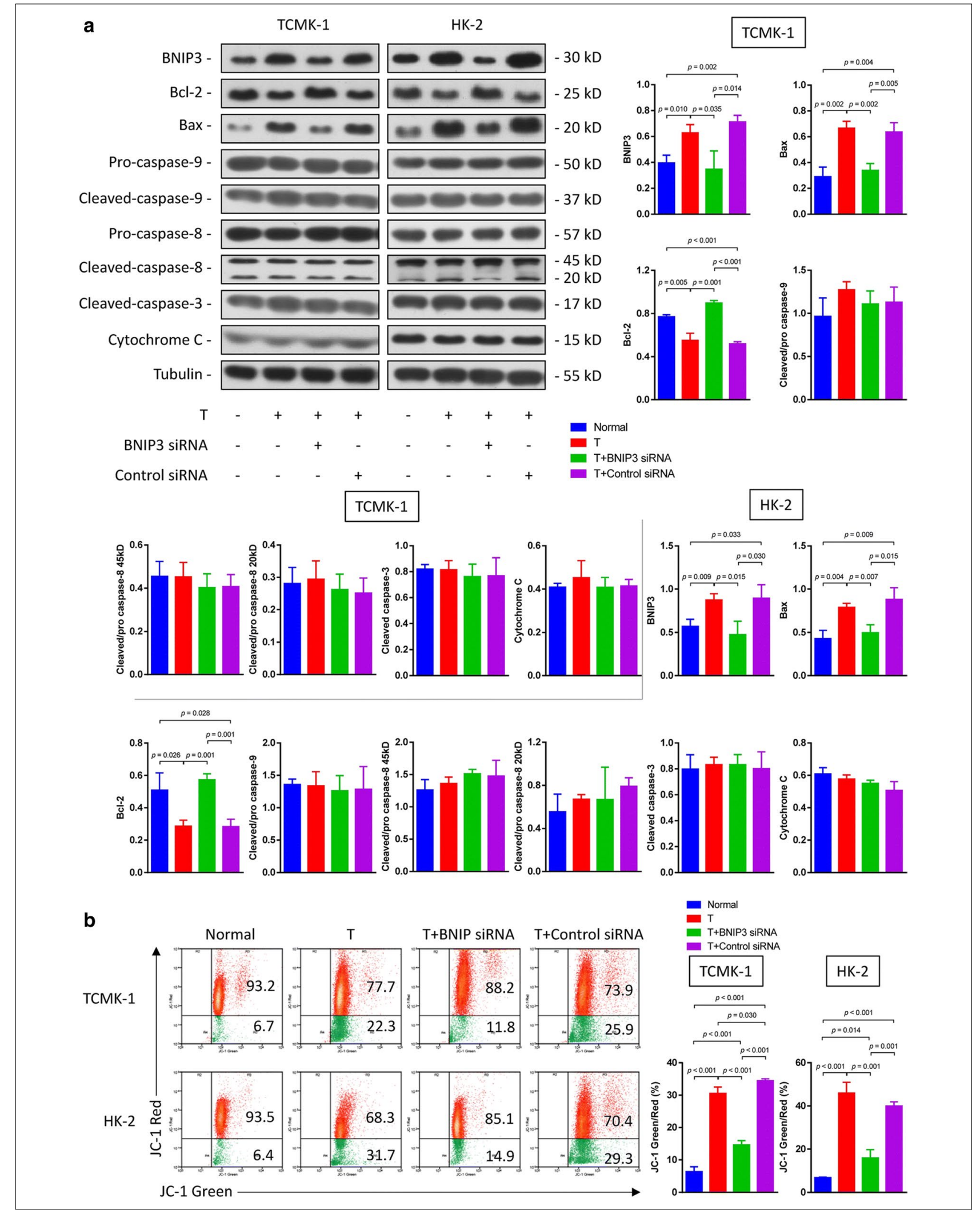




\section{Correct Figure 6:}

a

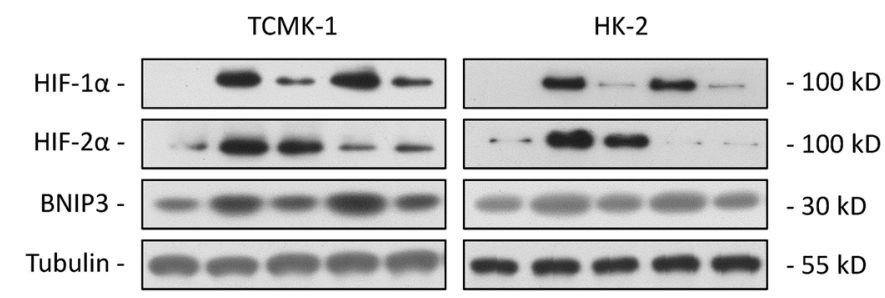

$\begin{array}{rrrrrrrrrrrrrr}\text { T } & - & + & + & + & + & - & + & + & + & + & \\ 400083 & - & - & + & - & - & - & - & + & - & - & \text { Normal } \\ \text { YC-1 } & - & - & - & + & - & - & - & - & + & - & T \\ T+400083 & T+Y C-1 \\ \text { T+400083+YC-1 }\end{array}$

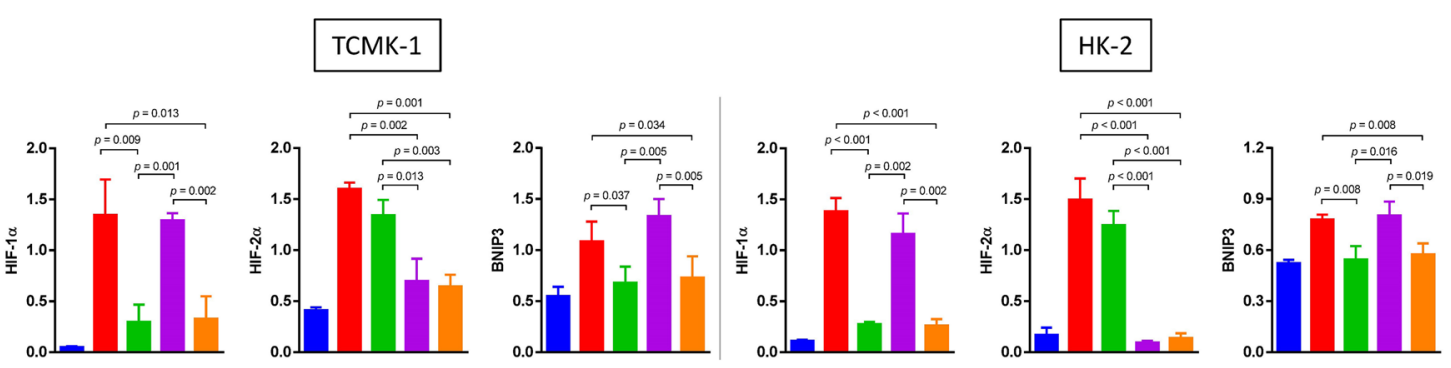

b

Normal

$\mathrm{T}$

$T+400083$

$\mathrm{T}+\mathrm{YC}-1$

$T+400083+Y C-1$
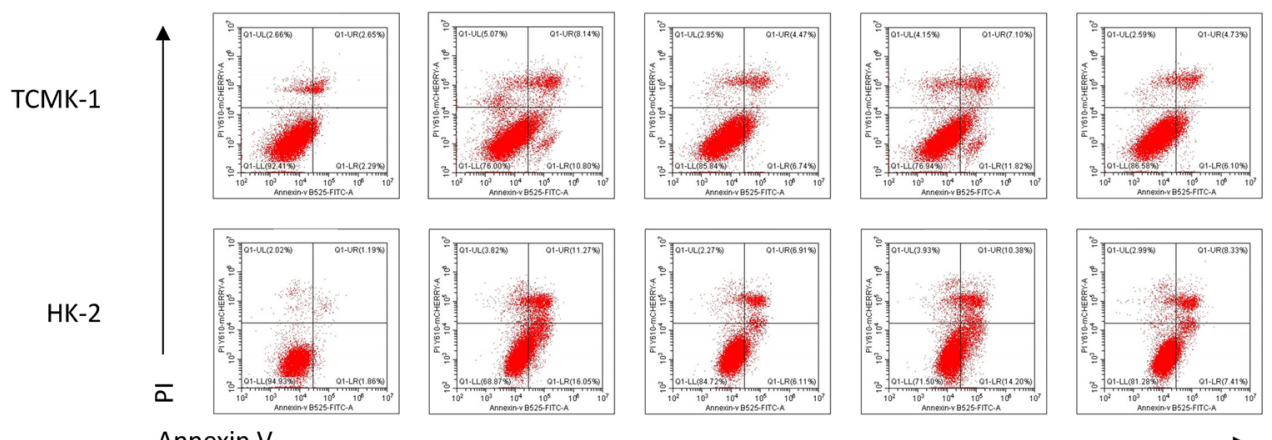

Annexin V
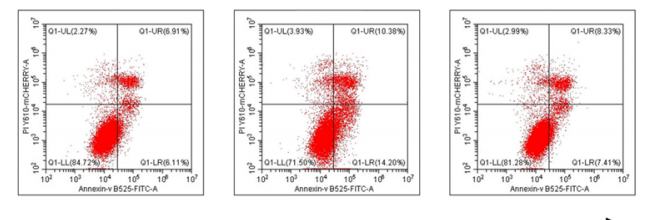

TCMK-1

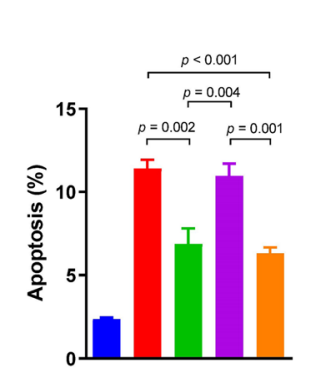

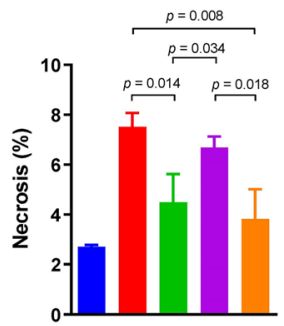

normal

- $\mathrm{T}$

- $T+400083$

- T+YC-1

- $T+400083+Y C-1$
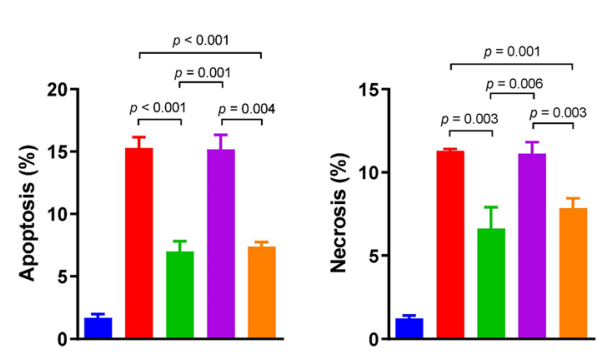


\section{Incorrect Figure 6:}

a

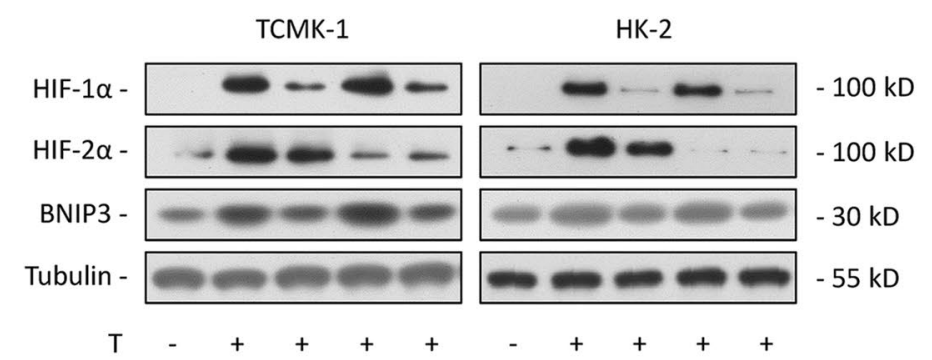

- Normal

- T

- $T+400083$

- $T+Y C-1$

- T+400083+YC-1

$400083+Y C-1$

\section{TCMK-1}

\section{HK-2}
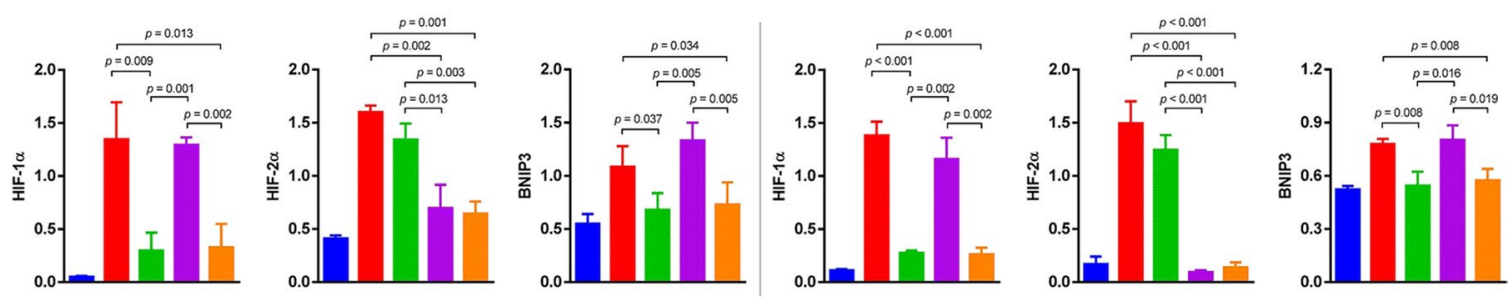

b

Normal

T

$\mathrm{T}+400083$

$\mathrm{T}+\mathrm{YC}-1$

$T+400083+Y C-1$
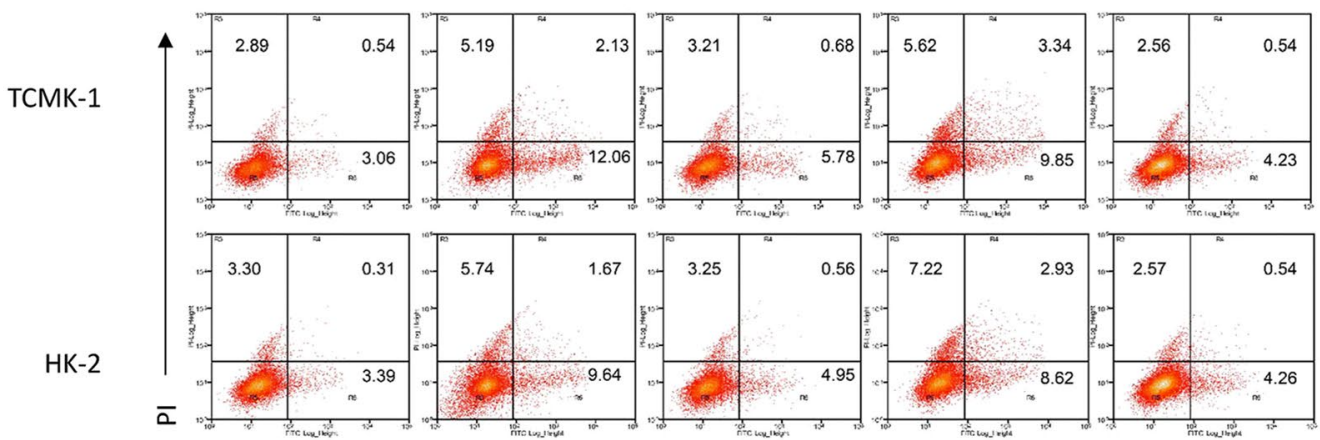

Annexin V
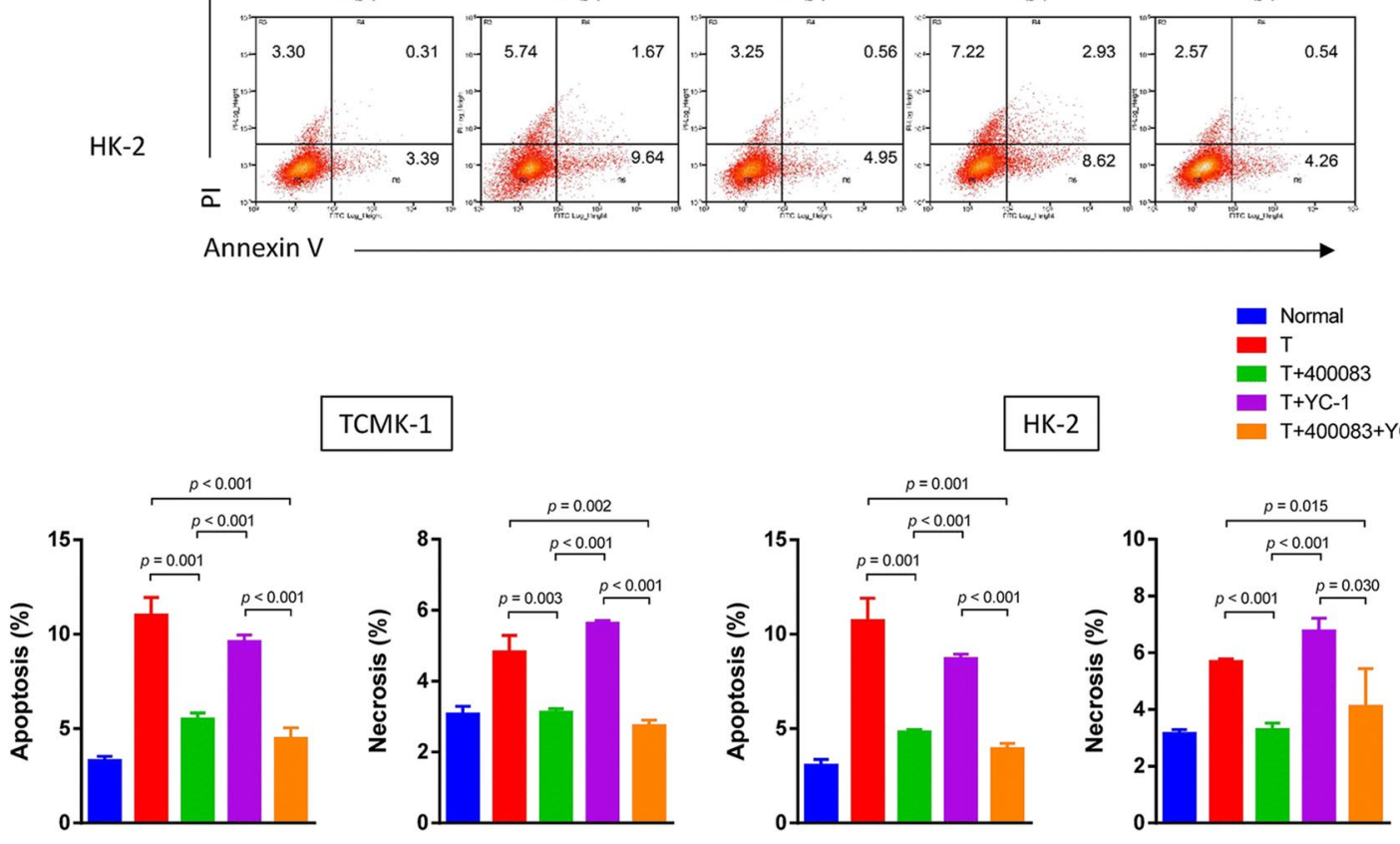


\section{Author details}

1 Department of Urology, Shanghai Changhai Hospital, Shanghai 200433,

China. ${ }^{2}$ Department of Urology, Zhongshan Hospital, Shanghai Key Laboratory of Organ Transplantation, Fudan University, 180 Fenglin Road, Shanghai 200032, China. ${ }^{3}$ Zhangjiang Institute of Fudan University, Shanghai 201203, China.

Published online: 12 April 2021

\section{Reference}

1. Peng Y, Fang Z, Liu M, Wang Z, Li L, Ming S, Lu C, Dong H, Zhang W, Wang Q, Shen R, Xie F, Zhang W, Yang C, Gao X, Sun Y. Testosterone induces renal tubular epithelial cell death through the HIF-1 a/BNIP3 pathway. J Transl Med. 2019;17:62. https://doi.org/10.1186/s12967-019-1821-7.

\section{Publisher's Note}

Springer Nature remains neutral with regard to jurisdictional claims in published maps and institutional affiliations.
Ready to submit your research? Choose BMC and benefit from:

- fast, convenient online submission

- thorough peer review by experienced researchers in your field

- rapid publication on acceptance

- support for research data, including large and complex data types

- gold Open Access which fosters wider collaboration and increased citations

- maximum visibility for your research: over $100 \mathrm{M}$ website views per year

At BMC, research is always in progress.

Learn more biomedcentral.com/submissions 